\title{
Pengaruh Kredibilitas Brand Ambassador Non-Celebrity Analisa Widyaningrum terhadap Keputusan Pembelian Hijabenka
}

\author{
Gaby Geraldine, Diah Ayu Candraningrum \\ geraldinegaby2@gmail.com,diahc@fikom.untar.ac.id \\ Fakultas Ilmu Komunikasi Universitas Tarumanagara
}

\begin{abstract}
The concept of brand ambassadors is now widely used by companies to bring out product excellence in order to attract consumer buying interest. Some people still assume that the brand ambassador is a public figure who is a famous celebrity. However, Hijabenka chose to use non-celebrity brand ambassadors or those who did not come from the entertainment world but by seeing special expertise to represent Hijabenka products. The question of this study is to look at the influence of non-celebrity brand ambassadors on purchasing decisions for Hijabenka products. Advertising models are grouped into three namely lay endorsers (celebrity undercover advertisements), celebrity endorsers (celebrities), and expertise (experts). This research was conducted with a mixed method research approach, namely quantitative data through questionnaires distributed to members of Hijabers Mom and qualitative data namely interviews with Hijabenka brand manager, The conclusion in this study states that there is an influence between non-celebrity brand ambassadors on Widyaningrum's analysis of decisions purchase of Hijabenka products. This is aimed at the compatibility between Hijabenka brand ambassador criteria and purchasing decision factors, especially the Hijabers Mom Community community.
\end{abstract}

Keywords: brand ambassador, decisions purchase, hijabenka

\begin{abstract}
Abstrak
Konsep brand ambassador sekarang ini mulai banyak digunakan oleh perusahaan untuk memunculkan keunggulan produk demi menarik minat beli konsumen. Sebagian kalangan masyarakat masih menganggap bahwa brand ambassador adalah seorang publik figur yang merupakan selebriti terkenal. Namun, Hijabenka memilih untuk menggunakan brand ambassador non-celebrity atau yang bukan berasal dari dunia hiburan tetapi dengan melihat keahlian khusus untuk mewakili produk Hijabenka. Pertanyaan dari penelitian ini adalah untuk melihat pengaruh brand ambassador non-celebrity terhadap keputusan pembelian produk Hijabenka. Model iklan dikelompokan menjadi tiga yaitu lay endorser (bintang iklan samaran), celebrity endorser (selebritis), dan expertise (para ahli). Penelitian ini dilakukan dengan pendekatan penelitian mixed method, yaitu data kuantitatif dengan melalui kuesioner yang disebar kepada anggota dari Hijabers Mom dan data kualitatif yaitu wawancara dengan brand manager Hijabenka, Kesimpulan dalam penelitian ini menyatakan bahwa terdapat pengaruh antara brand ambassador non-celebrity Analisa Widyaningrum terhadap keputusan pembelian produk Hijabenka. Hal ini ditujukan dengan kesesuaian antara kriteria brand ambassador Hijabenka dengan faktor keputusan pembelian khususnya komunitas Hijabers Mom Community.
\end{abstract}

Kata Kunci: brand ambassador, hijabenka, keputusan pembelian 


\section{Pendahuluan}

Saat ini, berbagai macam iklan produk hadir melalui televisi, radio, maupun media lainnya dan membuat konsumen pun semakin selektif dalam pemilihan produk. Belch \& Belch (2009), salah satu strategi yang sekarang ini mulai banyak digunakan perusahaan adalah memberikan informasi kepada konsumen melalui media periklanan. Dengan menyajikan ide-ide yang segar, unik dan tepat yang sesuai dengan target audiens. Menurut Lea-Greenwood dalam Budiman (2014) mendefinisikan brand ambassador sebagai sebuah alat yang digunakan perusahaan untuk berkomunikasi dan terhubung dengan masyarakat tentang bagaimana mereka benarbenar meningkatkan penjualan.

Menurut Doucett (2012) dalam Firmansyah (2019) mengatakan bahwa brand ambassador adalah seseorang yang mempunyai passion terhadap merek, mau memperkenalkannya, dan bahkan dengan sukarela memberikan informasi mengenai merek. Penggunaan brand ambassador biasanya dipilih berdasarkan citra melalui seorang selebriti yang terkenal. Secara umum, public figure sendiri merupakan orang yang mendapatkan perhatian media, dan sering merujuk dalam konsep selebriti, mengartikan public figure sebagai seseorang yang terkenal dan memiliki popularitas tinggi.

Dalam periklanan public figure adalah seorang bintang iklan yang bisa merupakan model iklan atau spokesperson. Model iklan merupakan seseorang yang memiliki karakter untuk mendukung produk yang diiklankan, dengan menyampaikan pesan dan memperagakan sebuah produk atau jasa (Belch, 2009).

Salah satu produsen pakaian yang menggunakan media periklanan untuk mengenalkan produk pakaian muslim adalah Hijabenka. Menurut Poppy Dharsono (2018) dalam wawancaranya dengan Kompas, Sekarang ini fashion adalah sebuah kecenderungan gaya yang sedang digemari pada saat itu dan berlaku dalam jangka waktu tertentu. karena merupakan pilihan pribadi setiap orang, yang bisa membuat diri mereka merasa lebih baik dan nyaman terutama untuk wanita berhijab.

Hijabenka merupakan label merek yang dikeluarkan oleh merek induknya yaitu Berrybenka. Hijabenka berhasil meraih keuntungan hingga 300\% pada awal peluncuran nya di tahun 2014 hingga 2015. Setiap tahunnya pun, merek label Hijabenka selalu paling banyak diminati oleh kaum perempuan muslim karena harganya yang terjangkau dan juga menggunakan bahan terbaik. Sejak produk diluncurkan ke pasaran, tahun 2018 Hijabenka menggunakan brand ambassador pertamanya yakni seorang psikolog dan juga spokesperson Analisa Widyaningrum.

Pemilihan Analisa sebagai brand ambassador oleh perusahaan tentu tidak sembarangan. Analisa yang memiliki banyak prestasi di bidang Psikologi, salah satunya membangun personality development center yang bernama APCD (Analisa Personality Development Center) yang merupakan salah satu sarana bagi setiap pribadi untuk terus mengasah diri dan meningkatkan kemampuan dalam menghadapi tantangan di masa depan.

Menurut Ohanian dalam Loggerenberg dan Wehmeyer (2009) dalam mengembangkan kredibilitas membagi menjadi 3 dimensi, yaitu expertise (keahlian), attractiveness (daya tarik), dan trustworthiness (kepercayaan). Keahlian atau Expertise merupakan keahlian model iklan yang dapat mengacu pada pengetahuan, 
pengalaman, dan keterampilan yang dimiliki berhubungan dengan topik yang diwakilinya. Keahlian mengenai informasi dapat disampaikan melalui sumber pesan dengan cara mempersepsikan produk yang diiklankan. Dengan ini diharapkan mereka mampu mewakili produk sehingga pesan yang disampaikan dapat diterima dan dipercaya konsumen.

Menurut pendapat Assauri (2013), Keputusan pembelian adalah suatu proses pengambilan keputusan pembelian yang mencakup penentuan apa yang akan dibeli atau tidak melakukan pembelian dan keputusan itu diperoleh dari kegiatan-kegiatan sebelumnya. Terdapat 5 tahap keputusan pembelian yaitu: pengenalan masalah, pencarian informasi, evaluasi alternatif, keputusan pembelian, perilaku pasca pembelian (Kotler, 2009).

Adapun rumusan masalah yang akan dibahas dalam penelitian ini yaitu "apakah ada pengaruh brand ambassador non celebrity Analisa Widyaningrum terhadap keputusan pembelian Hijabenka?" Sedangkan tujuan dari penelitian ini adalah untuk mengetahui kredibilitas brand ambassador Analisa Widyaningrum terhadap produk Hijabenka dan untuk mengetahui keputusan pembelian produk Hijabenka

\section{Metode Penelitian}

Dalam penelitian ini, penulis menggunakan pendekatan kuantitatif dan kualitatif (mixed method). Menurut Sarwono (2013) gabungan metode merupakan penggunaan dua atau lebih metode yang diambil dari dua pendekatan yang berbeda. Dalam penelitian ini pendekatan kuantitatif untuk melihat adanya pengaruh antara satu variabel $(\mathrm{X})$ terhadap variabel yang lain $(\mathrm{Y})$ yang mengandung artian bahwa adanya keharusan untuk mengukur besarnya efek variabel, dan pendekatan kualitatif digunakan untuk melihat bagaimana variabel (X) mempengaruhi variabel (Y).

Penelitian merupakan proses penyelidikan yang dilakukan secara hati-hati serta sistematis dalam mencari suatu fakta dan prinsip-prinsip suatu penyelidikan yang cermat guna menetapkan suatu keputusan yang tepat. Penelitian bertujuan untuk menemukan adanya hubungan yang akurat antar fenomena melalui analisis yang sistematik terhadap data empiris (Kriyantono, 2009)

Metode yang digunakan dalam penelitian ini adalah metode survei, yaitu metode yang menggunakan kuesioner sebagai bentuk pengumpulan data. Tujuannya adalah untuk memperoleh informasi tentang sejumlah responden yang dianggap mampu mewakili populasi tertentu (Kriyantono, 2009). Penelitian ini ditujukan kepada komunitas Hijabers di Jakarta yaitu Hijabers Mom Community untuk mengetahui hasil yang diperoleh dari variabel berupa keputusan membeli produk Hijabenka. Hijabers Mom Community merupakan salah satu komunitas Hijabers yang pernah mengikuti serangkaian kegiatan yang diselenggarakan Hijabenka bersama dengan Analisa Widyaningrum.

Teknik pengumpulan data dalam penelitian ini adalah data sekunder yang didapat melalui jurnal serta studi kepustakaan dari buku yang berkaitan dengan penelitian kemudian data primer peneliti menggunakan metode pengumpulan data yang berupa survei melalui kuesioner dan wawancara. Menurut Bambang (2010), kuesioner merupakan teknik pengumpulan data yang dilakukan dengan memberi seperangkat pertanyaan atau pernyataan tertulis kepada para responden untuk dijawab. Kuesioner yang akan dibuat akan berisi pernyataan sesuai dengan objek penelitian kepada responden yang telah ditentukan. Peneliti menggunakan bantuan 
google forms dalam teknik pengumpulan data dan meminta responden untuk memberikan jawaban, dengan menggunakan skala Likert, untuk mengukur sikap, pendapat atau persepsi seseorang atau kelompok tentang suatu objek (Kriyantono, 2009).

Menurut Bambang (2010), wawancara merupakan alat untuk mengecek ulang atau sebagai pembuktian terhadap keterangan yang diperoleh. Peneliti melakukan wawancara dengan brand manager Hijabenka untuk menggali lebih dalam tentang pemilihan Analisa Widyaningrum sebagai brand ambassador Hijabenka.

Analisis dari wawancara dengan langkah pertama yang peneliti lakukan adalah melakukan wawancara dengan narasumber yang berkaitan dengan masalah penelitian. Yang kemudian dilakukan triangulasi dengan sumber data dalam penelitian ini yaitu dengan membandingkan data hasil survei yang penulis lakukan dengan data hasil wawancara.

\section{Hasil Temuan Dan Diskusi}

\section{Karakteristik Responden}

Deskripsi data responden di dalam penelitian ini merupakan hasil dari data mentah (kuesioner) yang telah diolah dengan menggunakan teknik analisis data yang relevan dan akurat. Peneliti melakukan pengumpulan data melalui penyebaran kuesioner kepada 95 orang anggota dari Hijabers Mom Community Jakarta yang berjenis kelamin perempuan. Usia responden pada penelitian ini berusia 20-30 tahun. Dengan responden berumur 20-25 tahun sebanyak 41 orang dan usia 26-30 tahun sebanyak 54 orang.

\section{Hasil Dan Analisis Data}

Data mengenai Variabel X yaitu kredibilitas brand ambassador analisa Widyaningrum, dengan beberapa indikator yang menurut Ohanian dalam Loggerenberg dan Wehmeyer (2009) yaitu Attractiveness, Trustworthiness, dan Expertise. Hasil data responden diperoleh melalui perhitungan Google Form dengan jumlah 95 orang responden

Gambar 1. Pengumpulan data Google Form

Apakah brand ambassador memiliki personal yang menarik atau cantik?

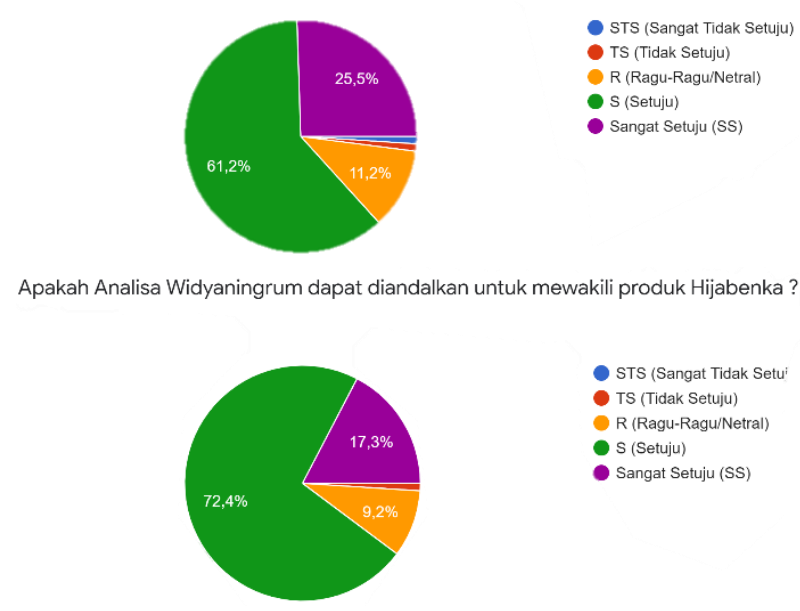


Berdasarkan hasil pengambilan data melalui kuesioner mengenai variabel $\mathrm{X}$ dalam penelitian ini, Analisa dianggap masyarakat khususnya Hijabers Mom Community dapat diandalkan sebagai brand ambassador karena keahliannya dalam bidang psikologi maka mampu mewakili wajah baru dari Hijabenka. Menurut Tellis (2008) dalam Aqsa (2015) Expertise merupakan keahlian model iklan yang dapat mengacu pada pengetahuan, pengalaman, dan keterampilan yang dimiliki berhubungan dengan topik yang diwakilinya.

Analisis data kualitatif bersifat induktif, sumber data kualitatif digunakan mode triangulasi teknik yakni terdiri dari observasi, wawancara dan dokumentasi. Hasil dari triangulasi tersebut masih bersifat umum dan banyak dilakukan (Sarwono, 2013). Dalam penelitian ini dilakukan wawancara dengan brand manager Hijabenka yaitu Gita Prisilfia. Berikut merupakan analisis data wawancara yang dilakukan penulis.

Berdasarkan hasil wawancara, didapatkan kriteria yang menjadi pemilihan brand ambassador atau muse untuk Hijabenka yaitu style, attitude, dan engagement. Dimana style atau gaya dari seorang brand ambassador harus sesuai dengan Hijabenka, selain itu juga attitude atau sikap dari seorang brand ambassador harus bisa menyesuaikan dengan jenis produk Hijabenka sehingga merek tersebut juga mendapatkan dampak yang positif, kemudian yang terakhir adalah dibandingkan menggunakan selebriti untuk mewakili wajah baru dari Hijabenka ia lebih ingin menunjukan sisi a real person dimana bukan hanya sebagai model namun seseorang yang bisa menyatu dengan Hijabenka. Menurut diagram diatas terdapat $61.2 \%$ responden setuju bahwa Analisa memiliki personal diri yang menarik dan juga cantik Penampilan diri yang menarik memegang peranan penting dalam pergaulan serta berhubungan.

Faktor physical attractiveness yang terdiri dari kecakapan atau kecantikan, modis, daya tarik, dan elegan. Penampilan diri yang menarik dapat dilihat dari memiliki kelebihan dari segi fisik (Shimp, 2010). Analisa Widyaningrum memiliki wajah yang cantik, serta memiliki gaya yang modis dan elegan. Wajah dari Analisa Widyaningrum ini menjadi daya tarik produsen Hijabenka untuk menjadikan Analisa menjadi model iklan.

Data mengenai variabel Y yaitu keputusan pembelian Hijabenka juga diukur melalui indikator pengenalan masalah, pencarian informasi, evaluasi alternatif, keputusan pembelian, perilaku pasca pembelian (Kotler, 2009). Hasil data responden diperoleh melalui pengisian Google Form dengan jumlah 95 orang responden.

Gambar 2. Pengumpulan data Google Form

Apakah adanya kebutuhan akan produk sehingga membeli produk Hijabenka ?

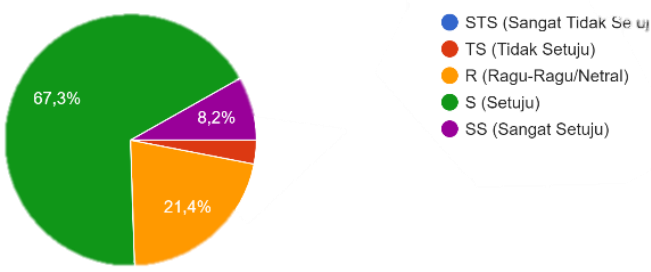


Diagram diatas menunjukan hasil perhitungan dari indikator faktor pengenalan masalah dimana proses pembelian diawali dengan adanya kebutuhan dari konsumen, kebutuhan tersebut didapatkan berdasarkan rangsangan internal (seperti: lapar, haus, dan sebagainya) dan eksternal (seperti: melihat iklan, promosi, dan sebagainya) maka tugas pemasar adalah mencari hal apa yang paling mempengaruhi minat konsumen (Kotler, 2009). angka setuju sebesar 67.30\% menunjukan bahwa terdapat kebutuhan akan produk Hijabenka sehingga dapat mempengaruhi keputusan membeli produk Hijabenka.

Gambar 3. Pengumpulan data Google Form

Apakah model iklan Hijabenka Analisa Widyaningrum mudah di ingat?
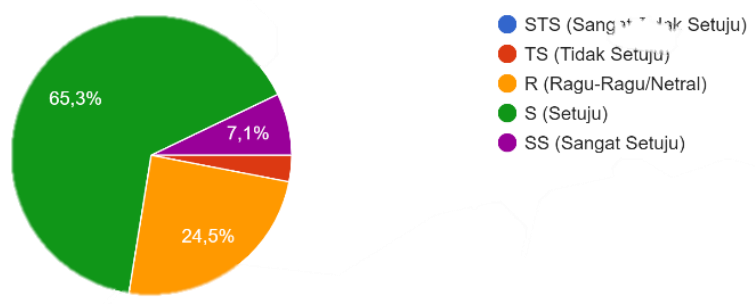

Ketika konsumen merasakan adanya kebutuhan akan sesuatu barang atau jasa, maka selanjutnya konsumen akan mencari informasi yang baik dan disimpan dalam ingatan (internal) maupun lingkungan (eksternal) dan informasi bisa berupa iklan, pribadi, dan pengalaman (Kotler,2009). Diagram diatas menggambarkan bagaimana Analisa Widyaningrum sebagai model iklan dari Hijabenka mampu mempengaruhi ingatan dari konsumen untuk melakukan keputusan pembelian.

Tagar dalam setiap unggahan foto Analisa Widyaningrum yaitu "TheNewHijabenka" dan "HijabenkaXme" merupakan salah satu pemasaran produk Hijabenka. Adanya tagar tersebut dengan foto Analisa menjadikan iklan Hijabenka mudah diingat oleh khalayak. Menurut Shimp (2010), mengingatkan merupakan fungsi dari periklanan, iklan yang efektif dapat mudah mengingatkan minat konsumen terhadap merek yang sudah ada dan pembelian sebuah merek.

Gambar 4. Pengumpulan data Google Form

Apakah popularitas Analisa Widyaningrum mempengaruhi untuk menggunakan produk Hijabenka?

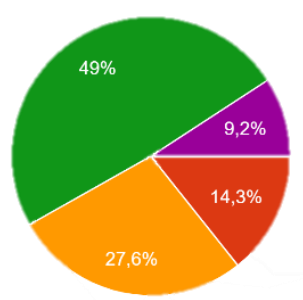

STS (Sangat Tidak Setuju)

TS (Tidak Setuju)

R (Ragu-Ragu/Netral)

S (Setuju)

- ss (Sangat Setuju) 
Pada tahap selanjutnya yaitu evaluasi alternatif dimana sesudah informasi diperoleh, konsumen akan melihat kembali alternatif pilihan dalam memenuhi kebutuhannya tersebut. Dengan menggunakan konsep dasar keterpercayaan terhadap merek, tingkat kesukaan dan fungsi kegunaan (Kotler dan Keller, 2009). Berdasarkan hasil wawancara dengan brand manager Hijabenka Gita Prisilfia juga mengatakan bahwa engagement dari brand ambassador nya harus baik dimana selain ingin mendapatkan penilaian positif dari konsumen, Hijabenka juga ingin mereknya mendapatkan peningkatan penjualan yang baik dengan adanya hubungan atau interaksi yang baik antara Analisa dan followers atau pengikutnya sehingga diharapkan mampu mempengaruhi keputusan pembelian.

Seseorang yang dipilih untuk mewakili product image, biasanya dari kalangan tokoh masyarakat yang memiliki karakter menonjol dan daya tarik yang kuat. Menurut Hardiman (2006) dalam Susantio dan Candraningrum (2019). Analisa Widyaningrum dikategorikan sebagai orang yang dipilih mewakili image sebuah produk karena merupakan seseorang psikolog klinis yang memiliki karakter menonjol yakni kecantikan serta kecerdasannya.

Berdasarkan hasil diagram yang berkaitan dengan indikator keputusan pembelian sebesar $49 \%$ responden setuju bahwa popularitas Analisa Widyaningrum cukup baik dalam mempengaruhi konsumen untuk menggunakan produk Hijabenka. Secara umum, public figure sendiri merupakan orang yang mendapatkan perhatian media, dan sering merujuk dalam konsep selebriti, mengartikan public figure sebagai seseorang yang terkenal dan memiliki popularitas tinggi.

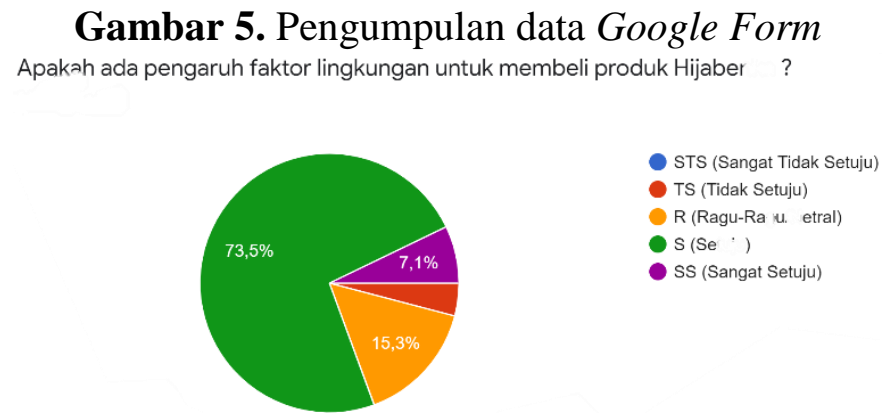

Diagram menunjukan lebih dari $70 \%$ suara mengatakan bahwa adanya faktor lingkungan yang mempengaruhi keputusan pembelian. Faktor lingkungan yang terdiri dari faktor budaya meliputi nilai-nilai norma yang dianut masyarakat, persepsi meliputi cara pandang sesuatu atau seseorang, kemudian preferensi yaitu rasa suka kepada suatu produk dibandingkan dengan produk lain dan behavior yaitu kebiasaan (Kotler, 2009). Hijabenka merupakan produk pakaian muslim yang mengikuti mode fashion terkini. Produk Hijabenka memang dirancang dan disesuaikan dengan kebutuhan fashion perempuan masa kini yang selalu ingin tampil sederhana namun stylish. Anggota dari Hijabers Mom Community yang melihat Analisa Widyaningrum disini merupakan mayoritas dalam meniru gaya berpakaian dan penampilan. Sebagai brand ambassador Analisa diharapkan mampu mempersuasi anggota Hijabers untuk mengikuti bergaya dengan fashion Hijabenka. 


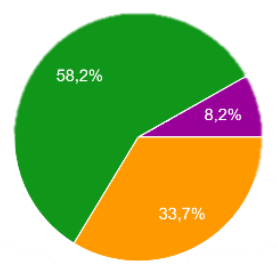

Selain itu tahap terakhir yakni perilaku pasca pembelian dimana puas dan ketidakpuasan konsumen bergantung terhadap suatu produk yang mempengaruhi perilaku pembelian konsumen selanjutnya (Kotler, 2009). Jika tidak sesuai dengan harapan maka konsumen akan kecewa namun jika sesuai harapan maka konsumen akan merasa puas. Dan hasil menunjukan 58.20\% responden setuju bahwa ada perasaan puas dalam menggunakan produk Hijabenka.

\section{Simpulan}

Berdasarkan hasil pengambilan data dan analisis data dari penelitian tentang pengaruh kredibilitas brand ambassador non-celebrity Analisa Widyaningrum terhadap Keputusan Pembelian Hijabenka adalah sebagai berikut:

1. Kredibilitas Analisa Widyaningrum atau variabel $\mathrm{X}$ dengan indikator trustworthiness didapat angka setuju terbesar yaitu $72.40 \%$ responden setuju bahwa Analisa Widyaningrum dapat diandalkan untuk mewakili produk Hijabenka. Berdasarkan data kualitatif diketahui bahwa kriteria yang menjadi pemilihan brand ambassador atau muse untuk Hijabenka yaitu style dan attitude. Dimana style dari seorang brand ambassador harus sesuai dengan Hijabenka, selain itu juga attitude dari seorang brand ambassador harus bisa menyesuaikan dengan jenis produk Hijabenka sehingga merek tersebut juga mendapatkan dampak yang positif, kemudian yang terakhir adalah dibandingkan menggunakan selebriti untuk mewakili wajah baru dari Hijabenka ia lebih ingin menunjukan sisi a real person dimana bukan hanya sebagai model namun seseorang yang bisa menyatu dengan Hijabenka.

2. Keputusan pembelian atau variabel $\mathrm{Y}$ demikian juga menurut data kuantitatif sesuai wawancara dengan brand manager Hijabenka bahwa ia ingin mereknya mendapatkan peningkatan penjualan yang baik dengan adanya hubungan atau interaksi yang baik antara Analisa dan followers atau pengikutnya sehingga diharapkan mampu mempengaruhi keputusan pembelian. Sesuai dengan beberapa faktor keputusan pembelian dengan angka setuju sebesar $49.90 \%$ yaitu popularitas Analisa Widyaningrum cukup baik dalam mempengaruhi konsumen untuk menggunakan produk Hijabenka. Kemudian adanya dorongan mental emosional dan terdapat $30.60 \%$ setuju dapat disimpulkan bahwa produk Hijabenka dibeli setelah melihat brand ambassador Analisa Widyaningrum, 
Gaby Geraldine, Diah Ayu Candraningrum: Pengaruh Kredibilitas Brand Ambassador Non-Celebrity Analisa Widyaningrum terhadap Keputusan Pembelian Hijabenka

\section{Ucapan Terima Kasih}

Peneliti mengucapkan terimakasih karena penelitian ini dapat terlaksana dengan bantuan seta dukungan dari banyak pihak. Oleh karena itu, peneliti ingin mengucapkan rasa terima kasih yang sebesar-besarnya kepada keluarga dan semua pihak yang ikut terlibat dan telah membantu peneliti selama proses penelitian ini berlangsung.

\section{Daftar Pustaka}

Assauri, Sofjan. Manajemen Pemasaran. Jakarta: Rajawali Pers. 2013

Belch, George. Advertising and Promotion: An Integrated Marketing Communications Perspective. New York: McGraw Hill. 2009

Firmansyah, Anang. Pemasaran Produk dan Merek: Planning dan Strategy, Jakarta: Qiara Media. 2019

Kotler, Philip. Manajemen Pemasaran, Edisi 13. Jakarta: Erlangga. 2009

Kriyantono, Rachmat. Teknik Praktis Riset Komunikasi. Jakarta: kencana Prenada Media Grup. 2009

Prasetyo, Bambang. Metode Penelitian Kuantitatif. Jakarta: PT. Raja Grafindo. 2010

Sarwono, Jonathan. Mixed Methods: Cara Menggabungkan Riset Kuantitatif dan Riset Kualitatif Secara Benar, Jakarta: PT.Elex Media Komputindo. 2013

Shimp, Terence A. Periklanan Promosi. Jakarta: Erlangga. 2010.

Aqsa. (2015). Pengaruh Kredibilitas Perusahaan dan Public Figure Dalam Periklanan Online Terhadap Sikap Konsumen. Jurnal Balance.

Wehmeyer, (2009). Celebrity Endorsements Versus Created Spokesperson In Advertising: A survey Among Students. Terarsip di: http://www.scielo.org.za/pdf/sajems/v12n1/07.pdf

Budiman, (2018) Peran Brand Ambassador Pada Iklan Dalam Membangun Brand Awareness (Studi Kasus Iklan Youtube LG G7 Thinq BTS). Jurnal Komunikasi, Terarsip di: https://journal.untar.ac.id/index.php/prologia/article/view/3743

Susantio, (2019). Pengaruh Brand Image Oi-Dakk Dengan Penggunaan Endorser Untuk Promosi Di Instagram Terhadap Minat Beli Konsumen. Terarsip di: https://journal.untar.ac.id/index.php/prologia/article/view/6246/4350

Tashandra, Nabilla. (2018, Maret 28). Poppy Dharsono: Fesyen Indonesia, Jadi Tuan Rumah di Negri Sendiri. September 16, 2019. Kompas.com. https://lifestyle.kompas.com/read/2018/03/28/165130320/poppy-dharsonofesyen-indonesia-jadilah-tuan-rumah-di-negeri-sendiri 